\title{
On the Sanskrit Manuscript of the "Śrāvakabhūmi"
}

\author{
Yasuo Matsunami
}

1

The present study aims at Sanskrit palm-leaf manuscript of the "Srāvakabhümi"1), which is now preserved in the China Library of Nationalities, Beijing. This manuscript of the "Srāvakabhūmi" is catalogued as numbers 20,21 , and $22^{2}$. As well-known to us, this manuscript contains not only Śrāvakabhūmi but also the other Bhūmis of Yogācārabhümi.

This manuscript is identified as the original manuscript which Rāhula Sānkrrtyāyana found and photographed at the Shalu Monastery, Tibet at the end of May in 1938 ${ }^{3}$. And the negatives of this photographed manuscript was brought to the Bihar Research Society in Patna, India. This photographed manuscript has been the ony source for the study of the Srävakabhümit ${ }^{4}$.

It is recently that we have come to know this original manuscript preserved in the China Library of Nationalites in Beijing.

The joint work begun in 1990 between the Institute for comprehensive study of Buddhism Taishō University and the China Library of Nationalites in Beijing made the outline of this original manuscript clearer.

By the result of the academic achievement of this joint work, the facsimile edition of the "Srāvakabhūmi" Sanskrit Palm-leaf Manuscript under the title of 大正大学綜仏教研究所 -中国民族図書館共編「中国民族図書館蔵梵文貝 葉写本・其二 声聞地 全六五葉」 will be pubhlished near future ${ }^{5)}$.

Fortunately the Srāvakabhūmi Study Group, which I also belong to, was allowed to use the microfilm from the original manuscript on the Śravakabhumi for our research ${ }^{6}$. Before our small interim report, we would better to survey the photographic copies of the manuscript on the Śrāvakabhumi, which we have used for our edition and our translation. We have used two 
( 30 ) On the Sanskrit Manuscript of the "Śrāvakabhūmi" (Matsunami)

kinds of photographic copies. The first photographic copies are those of being given from Prof. L. Schmithausen, Hamburg Uni.. The second ones are those of being borrowed from Prof. Isoda, Tohoku Uni.. Between the two, the latter are rather better materials for our edition and our translation. Because the latter ones were photocopied within the time when the negatives had been in good condition. And so sometimes letters are clear and distinct.

By the way it must be necessary to explain how the negatives, from which two kind of photocopies were made, had been produced. one negative contains 7 to 10 manuscripts. These manuscripts had been sticked on a board, hanged on a wall and photographed. Therefore these defects ocurrs naturally.

(1) In each manuscript some letters are hidden by the pushpin.

(2) In some cases letters are obscured by the overlapped two manuscripts.

(3) As the photographs had been taken abuot 50 years ago, so the negatives have become obscured and indistinct. As a matter of course, the photocopies from such negatives are obscured and indistinct.

(4) As such many manuscripts are contained in only one sheet of the negative, so in the enlarged photocopy, letters are blurred and obscured. Especially in the corner of the photocopy.

If we use the above-mentioned original manuscript, such a trouble will be easily conquered. Consequently we are now able to make up for the incompleteness of the study for the Srāvakabhūmi manuscript.

2

For the more research for the Srāvakabhümi manuscript, we would now show the some parts of its Collation Table.

Collation Table ${ }^{\text {) }}$

Ms.No. Rāhula Shukla Bhūmi $\quad$ P.

$\begin{array}{llcrl}\text { (1*a) } & 15 \mathrm{~A}-3 & \text { Cintāmayì bhūmi } & \text { Dsi } 245 \mathrm{a}^{7} \sim 246 \mathrm{~b}^{2} & 367 \mathrm{a}^{6} \sim 367 \mathrm{~b}^{13} \\ \text { (1*b) } & 15 \mathrm{~B}-3 & \prime \prime & 246 \mathrm{~b}^{2} \sim 247 \mathrm{~b}^{3} & 367 \mathrm{~b}^{13} \sim 367 \mathrm{c}^{15} \\ 2^{*} \mathrm{a} & 1 \mathrm{~A}-1 & \prime \prime & 247 \mathrm{~b}^{3} \sim 249 \mathrm{a}^{5} & 367 \mathrm{c}^{15} \sim 368 \mathrm{~b}^{3}\end{array}$


On the Sanskrit Manuscript of the "Śrāvakabhūmi" (MATsunAmi) ( 31 )

\begin{tabular}{|c|c|c|c|}
\hline $2 * b$ & $1 \mathrm{~B}-1$ & & $" \prime$ \\
\hline $3 * a$ & $15 \mathrm{~A}-6$ & & " \\
\hline $3 * b$ & $15 \mathrm{~B}-6$ & & $\prime \prime$ \\
\hline$(2 a)$ & $1 A-6$ & 5 & Śrāvakabhūmi \\
\hline$(2 b)$ & $1 \mathrm{~B}-6$ & 7 & $\prime \prime$ \\
\hline $3 a$ & $1 \mathrm{~A}-2$ & 10 & " \\
\hline $3 b$ & $1 \mathrm{~B}-2$ & 15 & " \\
\hline (4a) & $1 \mathrm{~B}-3$ & 17 & $\prime \prime$ \\
\hline$(4 b)$ & $1 \mathrm{~A}-3$ & 19 & " \\
\hline $6 a$ & $1 A-5$ & 67 & $" \prime$ \\
\hline $6 b$ & $1 \mathrm{~B}-5$ & 68 & " \\
\hline (7a) & $1 \mathrm{~A}-4$ & 70 & $\prime \prime$ \\
\hline$(7 b)$ & $1 \mathrm{~B}-4$ & 73 & " \\
\hline$(8 a)$ & $1 \mathrm{~A}-7$ & 55 & " \\
\hline$(8 b)$ & $1 \mathrm{~B}-7$ & 60 & $" \prime$ \\
\hline $9 \mathrm{a}$ & $1 \mathrm{~A}-8$ & 62 & "I \\
\hline $9 b^{-6 M}$ & $1 \mathrm{~B}-8$ & 65 & 11 \\
\hline $9 b^{6 M-}$ & $1 \mathrm{~B}-8$ & 46 & $" \prime$ \\
\hline $10 \mathrm{a}$ & $1 \mathrm{~A}-9$ & 46 & 11 \\
\hline
\end{tabular}

$$
\begin{array}{rlrl}
249 \mathrm{a}^{5} \sim 250 \mathrm{~b}^{1} & & 368 \mathrm{~b}^{3} \sim 368 \mathrm{c}^{22} \\
250 \mathrm{~b}^{1} \sim 252 \mathrm{a}^{1} & 368 \mathrm{c}^{22} \sim 369 \mathrm{~b}^{16} \\
252 \mathrm{a}^{2} \sim 253 \mathrm{~b}^{3} & 369 \mathrm{~b}^{16} \sim 370 \mathrm{a}^{9} \\
\text { Wi } \quad 4 \mathrm{a}^{2} \sim 5 \mathrm{a}^{6} & 396 \mathrm{~b}^{16} \sim 396 \mathrm{c}^{22} \\
5 \mathrm{a}^{5} \sim 6 \mathrm{~b}^{1} & 396 \mathrm{c}^{22} \sim 397 \mathrm{~b}^{4} \\
6 \mathrm{~b}^{1} \sim 7 \mathrm{~b}^{4} & 397 \mathrm{~b}^{5} \sim 397 \mathrm{c}^{11} \\
7 \mathrm{~b}^{4} \sim 8 \mathrm{~b}^{6} & 397 \mathrm{c}^{11} \sim 398 \mathrm{a}^{22} \\
8 \mathrm{~b}^{7} \sim 10 \mathrm{a}^{4} & 398 \mathrm{a}^{22} \sim 398 \mathrm{c}^{9} \\
10 \mathrm{a}^{5} \sim 11 \mathrm{a}^{6} & 398 \mathrm{c}^{9} \sim 399 \mathrm{a}^{24} \\
31 \mathrm{~b}^{7} \sim 32 \mathrm{~b}^{5} & 406 \mathrm{c}^{29} \sim 407 \mathrm{a}^{23} \\
32 \mathrm{~b}^{5} \sim 33 \mathrm{~b}^{7} & 407 \mathrm{a}^{24} \sim 407 \mathrm{~b}^{26} \\
33 \mathrm{~b}^{7} \sim 35 \mathrm{a}^{2} & 407 \mathrm{~b}^{26} \sim 408 \mathrm{a}^{5} \\
35 \mathrm{a}^{2} \sim 36 \mathrm{a}^{6} & 408 \mathrm{a}^{5} \sim 408 \mathrm{~b}^{6} \\
27 \mathrm{a}^{5} \sim 28 \mathrm{a}^{8} & 405 \mathrm{~b}^{5} \sim 405 \mathrm{c}^{14} \\
28 \mathrm{a}^{8} \sim 29 \mathrm{~b}^{8} & 405 \mathrm{c}^{14} \sim 406 \mathrm{a}^{28} \\
29 \mathrm{~b}^{8} \sim 31 \mathrm{a}^{1} & 406 \mathrm{a}^{28} \sim 406 \mathrm{c}^{8} \\
31 \mathrm{a}^{1} \sim 31 \mathrm{~b}^{7} & 406 \mathrm{c}^{8} \sim 406 \mathrm{c}^{29} \\
22 \mathrm{~b}^{4} \sim 22 \mathrm{~b}^{7} & 403 \mathrm{c}^{12} \sim 403 \mathrm{c}^{19} \\
22 \mathrm{~b}^{7} \sim 23 \mathrm{~b}^{8} & 403 \mathrm{c}^{19} \sim 404 \mathrm{a}^{24}
\end{array}
$$

$15 b^{-6 L} \quad 2 B-4 \quad 32 \quad$ Śrāvakabhūmi

$17 \mathrm{~b}^{3} \sim 18 \mathrm{a}^{8} \quad 401 \mathrm{c}^{13} \sim 402 \mathrm{a}^{16}$

$15 \mathrm{~b}^{6 \mathrm{~L}-} \quad 2 \mathrm{~B}-4$

Śrutamaȳi bhūmi

Dsi $210 \mathrm{a}^{7} \sim 210 \mathrm{~b}^{3}$

$354 b^{16} \sim 354 b^{22}$

$16 \mathrm{a} \quad 2 \mathrm{~A}-5$

$$
\text { ' }
$$$$
210 \mathrm{~b}^{3} \sim 211 \mathrm{~b}^{8} \quad 354 \mathrm{~b}^{22} \sim 355 \mathrm{a}^{6}
$$

$\begin{array}{lcccrc}128 \mathrm{~b} & 15 \mathrm{~B}-8 & 509 & \text { Śrāvakabhūmi } & 234 \mathrm{~b}^{7} \sim 236 \mathrm{a}^{3} & 477 \mathrm{a}^{21} \sim 477 \mathrm{c}^{1} \\ 129 \mathrm{a}^{-2 M} & 15 \mathrm{~A}-1 & 510 & \prime \prime & 236 \mathrm{a}^{3} \sim 236 \mathrm{a}^{8} & 477 \mathrm{c}^{1} \\ 129 \mathrm{a}^{2 \mathrm{M}}- & 15 \mathrm{~A}-1 & & \text { Pratyekabuddhabhūmi } & \text { Dsi } 326 \mathrm{~b}^{8} \sim 327 \mathrm{~b}^{5} & 477 \mathrm{c}^{2} \sim 477 \mathrm{c}^{24} \\ 129 \mathrm{~b} & 15 \mathrm{~B}-1 & & \prime \prime & 327 \mathrm{~b}^{5} \sim 328 \mathrm{~b}^{6} & 477 \mathrm{c}^{24} \sim 478 \mathrm{~b}^{1} \\ 130 \mathrm{a} & 15 \mathrm{~A}-2 & \text { Cintāmayī bhūmi } & 237 \mathrm{~b}^{8} \sim 239 \mathrm{a}^{2} & 364 \mathrm{a}^{18} \sim 364 \mathrm{~b}^{23} \\ 130 \mathrm{~b} & 15 \mathrm{~B}-2 & \prime \prime & 239 \mathrm{a}^{2} \sim 240 \mathrm{a}^{5} & 364 \mathrm{~b}^{23} \sim 364 \mathrm{c}^{29} \\ 131 \mathrm{a} & 15 \mathrm{~A}-5 & \prime \prime & 240 \mathrm{a}^{5} \sim 241 \mathrm{a}^{8} & 364 \mathrm{c}^{29} \sim 365 \mathrm{~b}^{2} \\ 131 \mathrm{~b} & 15 \mathrm{~B}-5 & & \prime \prime & 241 \mathrm{a}^{8} \sim 242 \mathrm{~b}^{6} & 365 \mathrm{~b}^{2} \sim 365 \mathrm{c}^{16} \\ \mathrm{~A} * \mathrm{a} & 15 \mathrm{~B}-4 & \text { (432) Śrāvakabhūmi } & \text { Wi } 193 \mathrm{~b}^{8} \sim 195 \mathrm{a}^{4} & 463 \mathrm{c}^{27} \sim 464 \mathrm{~b}^{6} \\ \mathrm{~A} * \mathrm{~b} & 15 \mathrm{~A}-4 & \text { (432) } & \prime \prime & 195 \mathrm{a}^{4} \sim 196 \mathrm{a}^{3} & 464 \mathrm{~b}^{6} \sim 464 \mathrm{c}^{6}\end{array}$


( 32 ) On the Sanskrit Manuscript of the "Śrāvakabhūmi" (MATsUnAMI)

$\begin{array}{lccrr}\mathrm{B}^{*} \mathrm{a}^{-6 \mathrm{~L}} & 15 \mathrm{~A}-7 & \text { Asamăhitā bhūmi } & \text { Dsi } 181 \mathrm{~b}^{7} \sim 182 \mathrm{~b}^{7} & 344 \mathrm{~b}^{19} \sim 344 \mathrm{c}^{15} \\ \mathrm{~B}^{*} \mathrm{a}^{6 \mathrm{~L}}- & 15 \mathrm{~A}-7 & \text { Sacittikā bhūmir acittikā } & \text { ca } 182 \mathrm{~b}^{7} \sim 183 \mathrm{a}^{3} & 344 \mathrm{c}^{16} \sim 344 \mathrm{c}^{24} \\ \mathrm{~B} * \mathrm{~b} & 15 \mathrm{~B}-7 & \prime \prime & 183 \mathrm{a}^{3} \sim 183 \mathrm{~b}^{8} & 344 \mathrm{c}^{24} \sim 345 \mathrm{a}^{16}\end{array}$

The following things must be pointed out.

(1) Some parts of the Śrāvakabhümi are missing. Before a folio number (2a) one folio must exist.

(2) The correct arrangement in order can't be got from the numbers fixed on the folios. For example a folio number $6 \mathrm{a}$ to $10 \mathrm{a}$.

(3) Passages of other bhumis is inserted at the beginning or the end of a leaf. Passages of the Śrutamaȳ bhümi begins at a folio number $15^{6 \mathrm{~L}}$.

(4) At least two types of the handwriting exist. For example, B*a is a different type of the handwriting from the others.

And more example, about (2), (3) and (4) is as follows ; both a folio $29^{1 \mathrm{R}}$ $-30^{8 \mathrm{~L}}$ and a folio $\mathrm{A}^{*} \mathrm{a}-\mathrm{A}^{*} \mathrm{~b}$ corespond to $\mathrm{P} 193 \mathrm{~b}^{8}-196 \mathrm{a}^{3}, \mathrm{Ch} 463 \mathrm{c}^{27}-464 \mathrm{~b}^{6}$.

These passages must be inserted between the 3rd line and 4 th line of P. 432 in the Sanskrit text of K. Shukla's. Therefore one set of the Srãvakabhūmi Manuscript has become to possess the same two passages. So one passage is supposed to be written on the basis of the other passage. ${ }^{9)}$

1) This small paper of mine owes very much to the paper "Introduction to the "Śrāvakabhūmi" Sanskrit Palm-leaf Manuscript", by Śrāvakabhūmi Study Group, Taishō University, Tokyo. I would like to express my best thanks to the other members of the Group. I am also thankful to them for their generosity to permit me to use the paper fully.

2) In the Catalogue of Sanskrit Palm-leaf Manuscripts Preserved in the Library of Nationalities (民族図書館蔵貝葉経目録)，No.20,21 and 22 are as follows;

No. 20 Śrävakabhūmi (126. leaves) No. 21 Pratyekabuddhabbūmi (1 leaf) No. 22 梵文残葉 But actually the No. 20 contains 127 leaves (Śrārakabhümi approximately 95 leaves, Cintāmayi bhümi approximately 24 leaves, Śrutamayī bhümi approximately 8 leaves), No. 21 contains 1 leaf on Pratyekabuddhabhūmi, No. 22 contains 7 leaves (Cintāmaȳ bhūmi 4 leaves, Srāvakabhūmi 2 leaves, Asamāhitā bhūmi approximately $\frac{1}{2}$ leaf, Sacittikā bhümi acittikā bhumi approximately $\frac{1}{2}$ leaf)

3) R. Sānkkṛtyāyana, "Search for Sanskrit Mss. in Tibet" JBORS 24-2, 1938, 
pp. $137-142$; p. 144, No. 350 . He also found other manuscripts on the Yogãcārabhumi at the Sakya monastery. He took photos of them and transcribed them. (do., "Second Search of Sanskrit Palm-leaf Mss. in Tibet", JBORS 231, 1937, p. 6 ; p. 19 ; p. 24 , No, 199 ; p. 55 , No. 16.)

4) 1 A. Wayman, Analysis of the Śrãvakabhūmi Manuscript, Berkley-Los Angeles, 1961.

2 K. Shukla, Śrāvakabhūmi of Ācārya Asañga, Patna, 1973

3 L, Schmithausen, "Die letzten Seiten der Śrāvakabhūmi”, Indological and Buddhist Studies, Volume in Honour of Professor J.W. de Jong on His sixtieth Birthday, Canberra, 1982.

4 大正大学声聞地研究会「梵文声聞地 $(-) 」 \sim$ 「同 $(+)\rfloor$, 東京, 1981 1991.

5）「日中仏教学術交流について」大正大学綜合仏教研究所通信 No.2, 大正大学綜合仏 教研究所, 東京, 1990, p. 1-p. 2 .

6) The editions and translations on the six other bhumis, contained in the Śrāvakabhūmi Manuscript, are as follows ;

1 Asamāhitā bhūmi

2 Sacittikā bhūmi 3 Acittikā bhūmi

A. Wayman, "The Sacittikā bhūmi and Acittikā bhūmi Text and Translation", Buddhist Insight, Delhi, 1984, pp. 327-331. (Śrvbk)

L. Schmithausen, Ālayavijñãna, Tokyo, 1987, pp. 220-222. (Ybh. Śrvbh)

4 Śrutamayī bhūmi

J. Pandey, Bauddhācārya Asaṅgakṛta Yogācārabhūmiśāstra mem Hetuvidyā, Homage to Bhikkhu J. Kashyap, Nālanda, 1986, pp. 315-350. (Ybh)

5 Cintāmayī bhūmi

A. Wayman, "Asanga's treatise, the Parāmartha-gātha” op. cit. pp. 333-352, "Asanga's treatise on the Three Instructions of Buddhism" op. cit. pp. 353-365. (Śrvbh)

Fumio Enomoto, "Śarīrārthagāthā, a Collection of Canonical Verses in the Yogācārabhūmi, Part 1: Text”, Sanskrit-Texte aus dem buddhistischen Kanon: Neuentdeckungen und Neueditionen, Göttingen, 1989, pp. 17-35. (Ybh. Śrvbh)

6 Pratyekabuddhabhūmi

A, Wayman, "The Sacittikā and Acittikā bhūmi and The Pratyekabuddhabhūmi", Journal of Indian and Buddhist Studies, 8-1, Tokyo, 1960, pp. 379-375. (Śrvbh)

J. Pandey, "Pratyeka-buddhabhūmi", Philosophical Essays, Professor A. Thakur Felicitation Volume, 1987, pp. 228-237. (Ybh)

[At the end of each item, the abbreviation (Śrvbh) means the paper which uses the Śrāvakabhūmi Manuscript and the abbreviation ( $Y b h$ ) 
( 34 ) On the Sanskrit Manuscript of the "Śrāvakabhūmi" (MATSUNAMI)

means the paper which uses the Yogācārabhūmi Manuscript.]

Some members of Śrāvakabhūmi Study Group shared the work to edit and to translate the parts where there are no editions and no translations. The result of such works will very soon be pubhlished.

1 Asamāhitā bhūmi

Yasuo Matsunami, 「焚文声聞地 (+-)」(“Sanskrit Śrāvakabhūmi (11)”), (Annual of the Institute for Gomprehensive Studies of Buddhism, Taishō University, No. 15, Tokyo, 1992. (in print)

4 Śrutamayi bhumi

Hideomi Yaita, "Hetuvidyā Section of the Yogācārabhūmi", Journal of Naritasan Institute for Buddhist Studies, Vol. 15, Narita, 1992. (in print) Yasuo Matsunami, op. cit.

5 Cintāmayī bhūmi

Takashi Meda, Ābhiprāyikārthagathānirdeśa (䣋意趣義伽他)」, BUNKA (Culture), The LITERARY SOCIETY, TOHOKU UNI., No. 54 1/2, Sendai, 1991. (in print)

7) Abbreviation for the Collation Table

Ms, No. A folio number put on a manuscript

( ) A folio number on a manuscript is indistinct

Asterisk* A manuscript without any folio numbers

L, M, R Each line of the manuscript is divided into three segments : left (L), middle (M), right (R)

$\mathrm{P}$ Tibetan version (Peking edition) of Yogācārabhūmi. The Tibetan Tripitaka, Tokyo-Kyoto, 1995-1961, No. 5536-5543, Vol. 109-111,

Ch Chinese version of Yogācārabhūmi. 大正大藏経30巻, No. 1579, Tokyo, 1924-1929.

9) Takayasu Kimura identified these folios for the first time, and published a critical edition. ("On the omission and its filling Śrāvakabhūmi in the Yogācārabhūmiśāstra" Journal of Indian and Buddhist Studies 40-2, Tokyo, 1992. (in print)

（文部省科学研究費平成 3 年度一般研究 $\mathrm{B}$ の成果である。）

〈Key Words〉Śrāvakabhūmi, 瑜伽論声聞地

(Lecturer of Taishō University) 